A Love Story by a Distinguished Russian Old-Believer 47 Storyteller from Latgalia

\title{
A Love Story by a Distinguished Russian Old-Believer Storyteller from Latgalia
}

Jelena Koroleva

Daugavpils State University

(Latvia)
Tatiana Filosofova

University of North Texas

(USA)

\section{Abstract}

The strong and vibrant Russian Old Believer community of Eastern Latvia (Latgalia district) produced many gifted artists, writers, poets and storytellers. Some of them went beyond the traditional topical limitations of Orthodox Christianity and wrote poetry and fiction on non-religious matters, such as love, family relations, history and the like. This research aims to bring to light one particular short story The Forced Love written by a self-made author of Old Believer origin, Maria Pakhomovna Blokhina (19262010) to a broader readership. The story has been heavily influenced by Russian folk tales and contains valuable insights of the local ethnography and dialect. This study offers an examination of the story's origins, plot, characters and language and aims to demonstrate the literary and folk heritage of the story, to demonstrate the story's ethnographic relevance of the period and to examine how the deliberate use of the local dialect by the author reveals her creativity in producing a text close to the style of a folk tale.

The Latgalian district of Latvia has been home to a community of 100,000 Russian Old Believers for more than 350 years. Today this community serves as an example of the successful preservation and development of the native culture and traditions in an environment dominated by other languages and religions. Russian Old Believers, who sought refuge beyond the Muscovite Rus' borders after the Church reforms of 1653-1667, began mass resettlement into the territory of contemporary Latvia during the second half of the $17^{\text {th }}$ century. The flow of Old Believers to Latvia, mainly from the priestless branch [беспоповцы поморского

FOLKLORICA 2016, Vol. XX 
согласие], grew especially strong in the $18^{\text {th }}$ and the beginning of the $19^{\text {th }}$ centuries. By the second half of the $19^{\text {th }}$ century, in the territory of contemporary Latvia, several large Old Believer centers developed in Riga, Jakobstadt (Jakabpils), Rezhica (Rezekne), and Dvinsk (Daugavpils). A tolerant attitude by the local authorities and locals towards the Russian Old Believers facilitated their successful integration into everyday life and has helped them to preserve their own culture, customs and traditions to the present day. Good education, in the best traditions of pre-reform Orthodox Christianity, played an important role in sustaining the traditional Old Believer worldview and their way of life. Therefore, it is no surprise, that educated and gifted literati were always the most respected members of the communities. Many of them produced a large number of theological works as well as religious poetry, songs and narratives. However, some Old Believer writers and storytellers went beyond these traditional topical limitations and wrote poetry and fiction on non-religious matters, such as love, family relations, history and the like.

Maria Pakhomovna Blokhina, from the village of Zui, was one of these gifted Old Believer storytellers, writers and artists, whose writings and art reflect local popular wisdom, morals and values. Her life and decorative folk style art drew the attention of the local press and television and made her a celebrity in Latvia. One could say that Maria Pakhomovna's media exposure challenged stereotypes of cloistered religious conservatives. This made her an epitome of a contemporary Russian Old Believer for the Latvian mass media. Journalists have written about Maria Blokhina's life and her work, especially her artistic talents. She was highly skilled at embroidery, knitting, and making soft toys. She presented her hand-embroidered carpets at numerous exhibitions. In all her works Maria Blokhina used original designs. While her crafting talents are widely recognized, journalists (and specialists) have, to date, ignored two other of Maria Blokhina's many talents: her writing skill and her gift as a wonderful storyteller. We believe that her writings in particular deserve serious review by scholars for one important reason: in Old Believer communities, work by literati like Maria Pakhomovna Blokhina helped establish a social sphere of folk 


\section{A Love Story by a Distinguished Russian Old-Believer 49 Storyteller from Latgalia}

creativity where they could express, in an artistic form, their understanding of contemporary history, society, life, morals and values.

This current research sets out to introduce to a broader readership one piece of fiction, Maria Blokhina's story The Forced Love. The Forced Love is set in an idyllic rural location of Latvia and tells us a rather lighthearted story of love between the son of a wealthy Latvian farmer, Valdis, and a poor, but clever and beautiful Russian girl, Paulina. After a few unsuccessful attempts to attract Paulina's attention, Valdis finally manages to overcome Paulina's coldness and persuades her to marry him. This event brings the story to a happy end. The Forced Love, due to the lighthearted plot, stands out from traditional writing by Old Believer authors, which typically discuss the morals and values of good Christians or theological matters. A close examination of The Forced Love can provide us valuable insights into the author's creative use of folk heritage, knowledge of local customs and dialect. Our analysis of the plot, characters, genre and the linguistic particularities of the story aims to achieve the following goals:

To demonstrate the literary and folk heritage of The Forced Love, by identifying the influence of fairy tales on the story. This results in the creation of a fictional story in the style of a hybrid folk tale, e.g., a literary folk tale; (1)

To demonstrate the story's ethnographic relevance of the period as the author skillfully uses her first-hand knowledge of the customs and traditions of the local farming community;

To examine how the deliberate use of the local dialect reveals the author's creativity in producing a text close to the style of a folk tale;

However, before examining the story, it would be beneficial to have a closer look at Maria Pakhomovna Blokhina's background. This overview will help us to understand better how the story was conceived, developed and completed.

FOLKLORICA 2016, Vol. XX 
About the Author

Maria Pakhomovna Blokhina (1926-2010), née Kuznetsova, was born in Riga in 1926 but spent her entire life in the village of Zui in the Rezhica (Rezekne) district. (2) Her father was a blacksmith in the village and had his own smithy there. Maria's mother worked away from home in Saint Petersburg and Riga. Therefore, her father had to care for his own children as well as for his disabled brother and his sister. At the age of 20 she married a local man. Being childless, she brought up two nephews from her husband's side of the family and left them two houses. During the Soviet era, Blokhina worked at a collective farm doing various sorts of manual labor. She was extremely proud to have received many awards from the local authorities for her farm labor. Blokhina did not have the opportunity to receive a formal education apart from three years at a primary school. She was self-taught and started writing and producing decorative art to fulfill her creative imagination. Maria Pakhomovna was an outgoing woman with many different interests. For example, she organized amateur theater performances and various cultural events at a local club. She was a popular person in the community and took part in charity work. She made it a practice to knit mittens and socks as Christmas presents for the children in the orphanage. During the Soviet era, several exhibitions of her art in Latvia featured her knitted crafts. Maria Pakhomovna also made many small colored rugs called podruchniki that Old Believers use during prayer. She donated these to many Old Believer churches in the country and abroad. She decorated all her podruchniki with an Old Believer cross, so that users would bow to the cross each time they prayed.

Professor Koroleva became acquainted with Maria Blokhina for the first time during an expedition in 1996 while recording the dialectal lexicon of the Old Believers of the Rezhica (Rezekne) district. It is worth mentioning that Professor Koroleva excluded Maria Pakhomovna from the list of her local informers, because her large and sophisticated vocabulary did not include examples of the local dialect lexicon. Ten years later, in 2006, Professor Koroleva met Maria Pakhomovna again. She observed that Blokhina's 


\section{A Love Story by a Distinguished Russian Old-Believer 51 Storyteller from Latgalia}

vocabulary had gone, unexpectedly, through some remarkable changes. Maria Pakhomovna had started to use much of the local dialect, words and idioms, skillfully inserting them into her speech. While Maria Pakhomovna did not explain her new linguistic preferences at the interview, she confirmed her clear understanding of the opposition of two versions of Russian; "natural village spoken language" (in other words, colloquial and dialectal forms), and "the bookish" or standard literary language. For example, she recalled that in the 1970s when she spoke at one of the conferences on Russian Old Believer studies, she was asked to speak her "natural language" in "the village manner," and she acquiesced to this request. It is remarkable that Maria Pakhomovna sounded natural when either speaking in local dialect or in standard Russian. She was also happy to explain the meaning and usage of the dialectal vocabulary in depth when asked to do so. Moreover, Blokhina employed her understanding of different linguistic registers in her literary work. (3)

During this second encounter with Professor Koroleva, Maria Pakhomovna mentioned for the first time that she had been writing poetry and fiction. She was eager to share her writings with a broader readership and permitted the publication of her work after her death. Maria Pakhomovna explained that she enjoyed writing, but had felt reticent about sharing her attempts at literary work. For many years Blokhina had been keeping a diary in addition to producing fiction. Her stories and poems are usually based on her own personal experiences. For example, one of her poems tells the story of a wounded Russian soldier rescued by her family during the Second World War. (4) Maria Pakhomovna also wrote witty fables on family relations that made fun of unfaithful husbands. However, as was mentioned above, the dramatic love story The Forced Love that is presented here stands out from the rest of her writings.

\section{The Origin of The Story}

The very fact that a meticulous, serious, and conscientious Old Believer produced a love story makes its origin even more intriguing. The title of the story is an oxymoron, and summarizes the 
story's content. The story focuses on a couple who were forced into a romantic relationship. However, the word "love" suggests an ultimately happy conclusion. The story is told in the first person as if it were Maria's personal experience. The narrator appears to be a 15-year-old shepherd girl named Masha, who witnessed a love affair between a poor farm worker, Paulina (sometimes also called Paula or Pauline), and Valdis, the son of a farm owner. Both Masha and Paulina worked together at his father's farm. It is notable that the narrator makes some surprisingly dry observations for a naïve 15year-old peasant girl, and we can hear in them the voice of the author. For example, the narrator makes the following remarks as the story is moving along: "вижу спектакль не очень приятный" [I can see the show is turning ugly]; "на этот спектакль обратили все внимание" everybody [was attracted by this show]. It is interesting to note that the narrator persistently uses the word спектакль [show] when describing the behavior of Valdis and Paulina. This indicates that the narrator perceives the relations between the two leading characters as rather theatrical and exaggerated and uses the word "show" in its figurative ironic meaning. (5) However, in her narration, Masha also conveys some of her personal feelings towards the leading characters. Her curiosity, envy and fear correspond more closely to a young girl's feelings.

Understanding the background of the characters to this story is particularly relevant to its literary importance. In fact, Blokhina's own biography was similar to the background of her fictional characters. Jelena Koroleva's interviews with Maria Pakhomovna [2006] confirm that during the Second World War, Maria worked for wealthy Latvians and that she was then 15 years old. Her father was sent to Germany to perform forced labor, and their family cattle were taken away. There were four children and a disabled uncle in the family. Their aunt had died, and they could not make ends meet. These interviews [Koroleva: 2006] also help us to distinguish her fictional characters from her real experiences. It is important to note that none of the story's characters are Russian Old Believers. Maria Pakhomovna was an extremely devout person who observed all the Old Believer religious traditions, everyday customs, and the strict

FOLKLORICA 2016, Vol. XX 


\section{A Love Story by a Distinguished Russian Old-Believer 53 Storyteller from Latgalia}

moral conduct that excludes frivolous behavior. As a devout Old Believer, the author could not possibly consider creating a lighthearted fictional love story about the Old Believers. It would be considered inappropriate at best and indecent at worst. Therefore, her fictional characters were outsiders who were not obliged to follow the strict rules of Old Believer communities. Blokhina uses different approaches in presenting her real life experiences and a fictional story based on these experiences. For example, both young Maria Pakhomovna and the narrator Masha had to go to work to help their families. However, in interviews [Koroleva: 2006] Maria Pakhomovna described her personal daily struggles surrounding being a poor girl, whereas the story totally lacks this dramatic aspect. In her discussions about the story, the author also insisted that the written story was fictional, though it is presented as if she had been a witness to all the events. Thus, this story is a fiction, not a biographical story, but it was certainly influenced by her own experiences.

It is also interesting that Maria Pakhomovna made two attempts to produce this story. She first started working on the story in 1960s, but did not complete it. She then returned to her work five years later. To appreciate this piece fully, we need to take in to consideration the author's lack of formal education beyond third grade. This fact explains the large number of spelling and grammatical mistakes in her writing. However, relying on her imagination and her gift for storytelling, Maria Pakhomovna managed to produce a fine story that reflects both an understanding of everyday life values by a regular person from a rural community of her time and the universal dream of a young girl about love and happiness.

\section{The Genre of the Story}

When presenting her work, Blokhina stressed to Professor Koroleva that she always had wanted to produce a fictional story, and her story The Forced Love was an attempt to achieve this goal. However, the plot, narrative and linguistic particularities of the story allow us to assert that, although Forced Love is a fictional story, it 
was heavily influenced by folk tales. On the basis of substantial experience of field work within functioning Old Believer communities, we have seen that influences occur naturally in literary writings by many self-made Old Believer writers. In addition to a good knowledge of the theological writings by the Old Believer authorities, a gifted Old Believer author would typically be familiar with mainstream Russian folk legends, tales and poetry. Maria Pakhomovna fits well to this profile. She knew many mainstream folk religious and epic poems, and could re-tell many folk tales and legends. Remarkably, she even extended her knowledge of mainstream Russian folklore to contemporary urban folklore. For example, she produced her own version of the popular political folk satire Gorbachev's Dream [Koroleva 2006]. (6) In The Forced Love we see influences of folk tales; in particular, in the plot, settings, narrative style and the language of the story. Its characters and plot closely resemble one of the universal fairy tale story lines, (a hero's quest for a princess), in the context of Latgalian rural community life of the 1940s. Valdis, the main male character, is the equivalent of a fairy tale hero who must fight for his love. Paulina, the main female character, could be considered a princess and a prize for the hero. Valdis had to make many attempts to win Paulina's love and overcome her coldness. The story takes place in Latvia during the Second World War. However, Blokhina focuses on the timeless universal value of true love that overcomes all difficulties and brings together two young and handsome people. The contemporaneity and location of events in the story give additional flavor to the narrative. For example, Valdis's unsuccessful, farcical attempt to commit suicide or the way that Paulina plays with Valdis's feelings resemble the melodrama of a television soap opera. In contrast, the accurate and vivid ethnographic details of life of the rural Latvian community, such as the beer-drinking festival, makes the love story similar to an oral folktale. (6)

The narration implemented by the author also resembles a folk tale where the narrator prefers to present a sequence of events rather than explain the logic behind the characters' actions. Maria Pakhomovna does not explain in detail the motives of her characters' actions. She leaves us to follow a sequence of events and 


\section{A Love Story by a Distinguished Russian Old-Believer 55 Storyteller from Latgalia}

to interpret them as we wish. We will turn to the development in the next section of this article. However, it would be fair to say that Blokhina employed her gifts as a storyteller to keep her readers amused. She was at ease turning her story from drama to melodrama, and from melodrama to farce when appropriate, relying on models both literary and folk that she knew well.

As mentioned above, the author considered her piece to be a fictional tale, albeit one based on her own life experience. Therefore, it would be beneficial to compare how Maria Pakhomovna presented the facts of her real life during the interviews [Koroleva: 2006] and how she built up a tale based on these facts. Many aspects of the tale The Forced Love clearly show the author's creativity. Unlike in her interviews [Koroleva: 2006], Maria Pakhomovna did not convey a sense of hardship of life during the Second World War in the tale. It is remarkable that even a harvest scene appears to be a timeless, colorful, and idealistic description of a happy rural life. She intentionally omitted themes of poverty, suffering, and daily struggle for survival as inappropriate to her tale of happy love. We consider how these settings also contribute to making the fictional love story, The Forced Love, similar to a folk tale. Blokhina aims to entertain her readership by creating an amusing sequence of events that culminate in Valdis's rather farcical attempt to commit suicide. The author also skillfully develops the function of the narrator Masha. It is notable that Masha at first appears to be only a witness of the events. However, in the second part of the story the narrator is transformed into a well-informed commentator on the events as they unfold.

\section{Plot and Characters}

As mentioned above, Maria Pakhomovna presents a sequence of events and does not explain either the characters' psychology or the motivation for their actions. However, two aspects of her writing style attract the reader's attention. First, the author pays significant attention to the appearances of the leading characters, Valdis and Paulina. Second, through the dialogue we learn information about the characters' background that helps us to understand and 
extrapolate motivations. For example, Maria Pakhomovna provides a positive description of Valdis as a young, handsome, passionate and loving man, (7) prompting sympathy towards him and his many unsuccessful attempts to make Paulina love him. Similarly, Paulina was also a very attractive young woman, prompting Valdis to fall in love with her at first sight. In describing Pauline's appearance, the author skillfully relies on an interesting comparison with a painted Madonna:

Паулина очень красивая девушка: глаза чёрные, искристые, волоса тёмные, вьющие, длинные, лицо смуглое с румянцем и статная фигура, между прочим, что разрисованная мадонна.

[Paulina is a very beautiful girl. Her eyes are black and sparkling, hair is dark, curly and long, face is darkcomplexioned with a blush and her figure is stately taking after a painted Madonna].

The author's choice of the participle "painted" and the noun "Madonna" are meaningful to the story's context. This particular comparison suggests that Paulina is a Catholic. Neither Russian Old Believers nor mainstream Russian Orthodox Churches allow the display of sculptures or paintings at home or in their churches. The image of the Virgin could only appear on icons within a restricted color range. The canonical image of the Virgin must have a veil covering all of her head, leaving only her pale face visible. Moreover, in Russian literary and folk tradition, the Virgin appears rather as a loving and suffering mother figure, and not as an attractive young woman. Therefore, the comparison between a beautiful, young girl and a painted Madonna likely refers to her Catholicism. It becomes clear that Valdis' family were Latvian Catholics as well. The author also refers to Valdis' family as an ordinary, hard-working family of a similar social class to Paulina. Therefore, at the very beginning of the story the author creates tension and invites us to solve an intriguing puzzle: why two young very handsome people from the same religious and social 


\section{A Love Story by a Distinguished Russian Old-Believer 57 Storyteller from Latgalia}

background cannot be together. A dialogue between Masha and Paulina hints at the source of Paulina's dislike for Valdis. Masha enquires about Paulina's coldness towards him, and Paulina explains by recounting her past. It seems that as children, Valdis teased Paulina, pulled her braids and called her "a little gypsy." During the course of the story, an additional reason for Paulina's strong dislike is revealed. She asserts her hatred towards the "aizsargs." The word "aizsargs" in Latvian describes the local proNazi military collaborators of which Valdis was a member. We need to take into consideration that the story was conceived and produced during Soviet times when the social perception of "aizsargs" was extremely negative. For this very reason, the author's desire to make an "aizsarg" a positive leading character seems rather extraordinary. However, the author does not dwell on the motivation for the social or political dissent between the leading characters. Rather, she focuses on universal human values, such as love and following one's heart, personal experience and popular wisdom. It seems that Blokhina is determined to achieve two different goals. On one hand, she aims to persuade her readers of the realistic nature of her story by setting it in a precise time (World War II), providing familiar settings to her readers (Latvian farming community) and underlining her protagonist's political views (Valdis was a Nazi collaborator). On the other hand, the author did not intend to develop further any of the above mentioned details. This may appear puzzling and even contradictory at the first reading. However, this writing style can often be observed in a literary story that was written in the style of a folk tale, where such realistic details provide background, but are not central to the plot.

The first sentence of the love story sets the plot in motion: a group of hunters and their hounds gathered to hunt at the farm. In the afternoon, the hunters returned to the farm with a dead deer. The author's choice of game has some additional resonance as well. The deer may be associated with a common part of the interior design of the house. In the 1960s, tapestry carpets from Germany were popular in the Latvian household. They typically depict diverse scenes, but a deer hunt was one of the most common. The use of a defenseless deer chased by hunters as a metaphor for a young, timid 
girl chased by men is essential to this tale. The hunt then serves two functions. The figure of the hunted deer acts as a metaphor for Valdis' pursuit of his beloved Paulina, as well as sets the scene for the daily life of the village that is central to this story.

In the course of the story, Valdis makes numerous unsuccessful attempts to court Paulina. The reader learns that, Valdis's advances notwithstanding, Paulina cannot forget her anger towards her beau. Rather, her angry, fierce, and strong dislike towards her unfortunate admirer grows each day. At this point, the author turns from melodrama to farce. After Paulina's final refusal of marriage, Valdis becomes furious and makes an unsuccessful attempt to commit suicide. Valdis shoots into the ceiling, his mother faints as she hears the shot, and the sound of her fall is so loud that Valdis runs up to his mother and tries to bring her to her senses. When she regains consciousness and sees Valdis, she believes that he has killed Paulina and faints again. Valdis then calls Paulina to rouse his mother. Finally, as a result of their joint efforts, she comes to, sees them together and asks whom he had killed. Valdis replies, "A fly on the ceiling." As we see, the final scene showcases the author's sense of humor and results in a rather farcical, albeit happy, ending. The couple do eventually marry and the author concludes the story with the lines:

До родов оставалось совсем немного времени. Валдис уговаривал жену не бояться при родах. Он говорил, я сам буду присутствовать при родах и говорил в шутку, ведь я без одной недели хирург.

[Two months remained until the delivery of the child. Valdis persuaded his wife not to be afraid, he told her that he would be present at the delivery himself and said jokingly, remember that I will be a surgeon in one week.]

The Ethnographic Value of the Story Settings

Above, we explored the core plot elements that advance Blokhina's story The Forced Love. However, it would be beneficial for us to examine the story's settings as well. Maria Pakhomovna FOLKLORICA 2016, Vol. XX 


\section{A Love Story by a Distinguished Russian Old-Believer 59 Storyteller from Latgalia}

was determined to make her story realistic [Koroleva: 2006]. She achieved this goal by providing a vivid description of a beer drinking culture and a typical harvest time on a farm in Latvia would be familiar to her intended readership. We also consider the detailed description of traditions and everyday customs of a Latvian rural community has its own ethnographic value. For example, she produced a very believable description of milling when landowners, together with their workers, grind corn for the entire neighborhood taking the mill from house to house:

Бривкалнс - хозяин зажиточный, хлеба много, рабочих собрал на две смены, работали по два часа и снова менялись. На обед столы накрывали в большом зале и в первую очередь посадили обедать хозяинов и их сынов и дочек, а работников и работниц во вторую застолицу.

[Brivkalns is a well-to-do landowner, having much corn; he gathered workers on two shifts, working for two hours and then exchanging shifts. For dinner, tables were laid in the big hall and the first to dine were the landowners with their sons and daughters; the workers dined in the second turn.]

From her description of the dinner that follows, we learn more about social tensions between the background characters, the landowners and the workers: "Рабочие начали роптать, мол, мы, свиньи, должны обедать после господ" [The workers started grumbling: we pigs must eat after masters]. However, Blokhina was not interested in the theme of social inequality and left her readers to interpret the potential tension between landowners and workers as the natural human desire to get an extra glass of beer. Thus, she turns the tale setting into a picturesque description of the happy idealistic life of a rural community:

На этот раз ужинать в первую очередь пригласили работников, и снова начался ропот, что в первой застолице надо торопиться, чтоб дать место другой, а другая может не торопиться, сидеть, сколько им захочется, торопить никто не станет, работа кончен.

FOLKLORICA 2016, Vol. XX 
Работали больше мужчины, им жаль было упустить лишнюю кружку пива... После ужины разобрали столы, и начались танцы. Играть были приглашены два аккордеониста, молодые красивые парни, они играли посменно.

[This time workers were invited to eat first and there was grumbling again that those who eat first must hurry in order to make room for the second turn that need not hurry and may sit as long as they like because the work is finished. The workers were mostly men and they were reluctant to miss another jug of beer....After supper the tables were taken away and people started dancing. Two accordionists had been invited to play, they were young handsome guys and played in turns.]

In this passage Blokhina demonstrates her ability to provide true vivid, ethnographic details that reflect the local color. For example, the beer-drinking culture played a significant role in a Latvian rural community. Beer was a traditional drink at all family and community rituals, celebrations and holidays. All local communities brewed plenty of beer in preparation for the work done together by the community (such as harvest, which was known as "toloka" in Latvia). In addition, an accordion and dancing have always been an essential part of any traditional celebration at Latvian holidays. Maria Pakhomovna creates a smoother narrative, because she knew well all the details of everyday life of that time. It is notable that the author strives to use numerous adjectives that makes her narratives lively and easy to follow. For example, during milling, Valdis did not approach the girls; the work was very hard, but Paulina continued mocking him: "Сегодня на твоих нежных руках появятся кровавые музули" [Today the soft hands will get bloody blisters]. In her brief description of the main characters, she also directs her attention to some important details of everyday life, such as a mandatory wash before attending the community dinner, and dressing smart for the community event: 


\section{A Love Story by a Distinguished Russian Old-Believer 61 Storyteller from Latgalia}

Хозяйки вынесли на двор теплую воду в ведрах и тазах, а также мыло и полотенце. Все вымылись, у кого была запасная одежда, переоделись. Валдис уехал домой, мы с Паулой зашли в работницкую комнату, там лежала наша запасная одежда, переоделись, расчесали свои волоса, поскольку они у нас были длинные, но за день тяжелой работы они растрепались и сбились, заплели косы, уложили аккуратно, переоделись. Когда все были уже в порядке и все собрались, хозяйки пригласили на ужин. Явился и Валдис в голубой рубашке, галифе и начищенных до блеска хромовых сапогах.

[The landlady brought out into the yard warm water in pails and bowls as well as soap and towels. Everybody washed and changed into fresh clothes. Valdis left for home but Paulina and I went into the worker's room; there were our spare clothes, there we brushed our hair as it was long and had got disheveled during the hard working day, we did our hair and changed. When everyone was ready and all had gathered, landladies invited us to supper. Valdis came dressed in a blue shirt, riding-breeches and polished shiny boots.]

Maria Pakhomovna reveals her gift as storyteller through a realistic detailed description of customs and traditions of the Latvian rural community that reflect important ethnographic information about the period. These vivid descriptions also made her tale believable and relevant to her intended audience.

The Story's Language

The story The Forced Love is written in the local dialect of Russian that is still spoken in Latgalia (the southeastern district of contemporary Latvia) where Maria Pahomovna lived all her life. The natural usage of this vocabulary by the author indicates both the folk roots of the story and the peasant origin of the author; a gifted self-made person who lacked a formal education. 
Regrettably, the absence of data concerning the non-religious fictional writings by Old Believer authors does not allow us to examine Blokhina's writings in this context. However, it is worth mentioning here a work by another distinguished Russian Old Believer storyteller and writer, D. T. Zaitsev. His biographical piece entitled Повесть и житие Даниль Терентьевича Зайцева [The Tale and the Life of Daniil Terent'evich Zaitsev] has been recently published by O. G. Rovnova [2015]. Although these two pieces represent two different genres, one a narrative fiction and one a biography, they are both written in an "unspoiled Russian folk language" [Rovnova, 2015: 15]. We believe that further comprehensive studies of narratives on non-religious topics would be beneficial for establishing some linguistic patterns in the nonreligious writings that have been established in the Old Believer communities. Here we will focus on the distinctive local features present in this story.

As we mentioned earlier, Maria Pakhomovna had a comprehensive knowledge of the local Latgalian dialect and understood well how to use different linguistic registers to enhance her story. Textual analysis of The Forced Love, in particular, demonstrates interesting particulars of the author's style. As noted above, Maria Pakhomovna had only a third-grade education. However, she strived to make her written language rich and expressive. For example, she produced a number of similes and metaphors in the story that merit comment. While many of them are rather common, she used them to make her writing more colorful. They include the following:

Я была похожа на бесенка, чумазая, вся в пыли, глаза слипались, хотелось спать. [I looked like a little devil, black-faced, covered with dust, I could hardly keep my eyes open, I felt like sleeping.]

Валдис молчал, он был бледный как лист бумаги [Valdis kept silent, he was pale as a sheet of paper];

Слезы катились крупные, как горох [The tears were 


\section{A Love Story by a Distinguished Russian Old-Believer 63 Storyteller from Latgalia}

rolling down as big as peas];

Она лежала, как мертвая [She was lying like a dead person];

Мать лепетала как птичка своим нежным голоском [The mother was twittering like a bird with her tender voice].

However, some of the author's metaphors are more original, as in “Она так и разливалась” [her words were flowing like a stream]. In her search for expressivity, Maria Pakhomovna also modified a well-known proverb “Долг платежом красен” [The debt must be honored by the payback]. In her version, it reads as "Долг отдачей красен" [The debt must be honored by the return]. Blokhina also created her own idioms for example, "скушать смешное" [to eat something funny] - “О чем вы смеетесь, что смешное скушали?” [What are you laughing at, have you eaten something funny?].

The author's vocabulary included some rare words from the vernacular. For example, she skillfully used the verb "брыснуть" made from the interjection "shoo": "Он снова на нее брыснул" [Не shooed her again]. Local dialectal lexicon and colloquial forms saturate the story as well, as one would expect for a story that can be classified as a folk tale, as we have argued. The comparative table below demonstrates some examples of the dialect forms that appeared in the story and their standard forms.

\begin{tabular}{|l|l|}
\hline Dialect and colloquial forms & Standard literary forms \\
\hline беремя (old form/dialect) & бремя [burden] \\
\hline застолица (dialect) & застолье [feast] \\
\hline $\begin{array}{l}\text { братенник } \\
\text { (dialect/colloquial) }\end{array}$ & брат [brother] \\
\hline отстебать (dialect) & отхлестать [to whip] \\
\hline подграбить (dialect) & подгрести [to rake] \\
\hline
\end{tabular}

FOLKLORICA 2016, Vol. XX 


\begin{tabular}{|l|l|}
\hline перечитывать (dialect) & перечислять [to list] \\
\hline работать работу (dialect) & $\begin{array}{l}\text { выполнять/делать работу [to } \\
\text { do a job/to work] }\end{array}$ \\
\hline co всех сил (colloquial) & $\begin{array}{l}\text { изо всех сил [to the best of } \\
\text { оne's abilities] }\end{array}$ \\
\hline $\begin{array}{l}\text { пасть в обморок } \\
\text { (dialect/colloquial) }\end{array}$ & упасть в обморок [to fade] \\
\hline
\end{tabular}

We also see features of dialectal morphology and syntax ; for example, the word "potato" [картофель] is classified as feminine gender instead of masculine and the omission of the subject of the clause of the sentence, the pronoun those [те]: “[Те] Которые освободились от других работ, обчасывали стог граблями, а солому подпихивали к Валидису" [Who were free from other work, raked around the stack pushing the straw towards Valdis]. Disagreement in the gender or number between short forms of participles and the subject of the sentence also commonly occur in the text as in the following examples:

Работа кончен [the work is done] - the feminine gender of the noun работа does not correspond to the masculine gender of the short participle кончен.

Лошадь была уж запряжен [the horse was harnessed] - the feminine gender of the noun лошадь does not correspond to the masculine gender of the short participle запряжен.

Срезан горки [the top is cut off] - the singular number of the short participle срезан does not agree with the plural form of the noun горки.

Глаза его были наполнен слезами [there were tears in his eyes] - the singular number of the short participle наполнен 


\section{A Love Story by a Distinguished Russian Old-Believer 65 Storyteller from Latgalia}

does not agree with the plural form of the noun глаза.

While her dialect features are well attested, another interesting particularity of the author's style are her attempts to use a "high" literary style that she considered prestigious. The author mixed linguistic registers and replaced selected dialect words with their "bookish" forms. This resulted in some vocabulary (shown in bold) that sound inappropriate in a casual context:

Хозяйка взялась стряпать и привлекла меня с Павлиной [The landlady started cooking and involved me and Paulina];

Взглянув на него, Паула улыбнулась и молвила: “А следки еще остались” [Looking at him Paulina smiled and said, "but traces still remained"];

Все бросили взор на них, даже в зале воцарила тишина. [Everybody looked at them, silence ensued even in the hall];

Я далеко отстала от ночного финиша [I am lagging long behind the nightly finish].

... обращался он больше к Паулине, смеялся, шутил, в отдельных случаях критиковал только себя [... he addressed mostly Paulina, laughing and joking, sometimes criticizing only himself]

Разбирала по категориям и носила в буфет посуду [Sorted dishes according to their type and carried them to the sideboard];

Хозяйка просила нам ей помочь в приготовлении - и опять монстр - добавочной пищи [The landlady asked us to help her in preparing - and another monstrosity additional food].

Sometimes the author's desire to implement a "bookish" style makes the text unintentionally funny. For example, Хозяйка 
пустила в ход все горло [The landlady put her whole lungs into action]. The appropriate use of the idiom would be: Хозяйка закричала во все горло [The landlady started to shout loudly]. Occasionally, the author uses prepositions that are grammatically incorrect in the literary standard as in, Хозяйка начала звонить по телефону и приглашать всех, кто участвовал на охоте [The landlady started telephoning and inviting all who had taken part in hunting]. The appropriate use of the prepositions на/в in Russian in this case as follows: кто участвовал в охоте / кто был на охоте.

To conclude our observations of Maria Pakhomovna's writing style, we turn once again to her interviews [Koroleva: 2006]. In her writings she displays her own understanding of language "correctness" and "suitability". In her poetry that describes realistic and tragic events of the World War II she deliberately avoids any dialectal lexicon in her attempt to produce a piece of work in "high" style. However, in the down-to-earth stories, such as The Forced Love, she attempts to use both forms of Russian as she thinks fit.

\section{Conclusion}

Maria Pakhomovna was a multitalented, self-educated and selfmade person. Her decorative artwork and her writings represent an area of folk creativity that lies on the border of collective anonymous folk tradition and, literary works produced in a folk style by a person of underprivileged background. The story The Forced Love, in particular, has many scholarly points of interest. First, this is a rare attempt to produce a fictional love story by an author from an Old Believer background. This breaks the traditional pattern of literary work by the Old Believer literati who usually would limit their writings to religious matters. We have argued that the story should be classified as literary fiction influenced by a folk tale. This influence can be seen, in particular, in the story's theme, its plot development and characters, and in its language. Secondly, the language of The Forced Love is potentially a source for study of a local Latgalian dialect. Usage of the dialectal form of Russian in the story should be considered as an advantage, not a shortcoming of this work. Thirdly level of ethnographic detail in the setting of the 


\section{A Love Story by a Distinguished Russian Old-Believer 67 Storyteller from Latgalia}

story displays her knowledge of and understanding of everyday life in a Latvian village of the 1940s. Finally, the author avoids any ideological positions and is an acute observer of human character and behavior. Maria Pakhomovna Blokhina takes up the universal plot of a love story, but develops it in her original way that introduces us to popular wisdom and everyday life values of the period in her village.

Below follows the entire text, without modifications from the original manuscript, of The Forced Love.

\section{NOTES}

1 Literary fairy tales have proved to be a very popular genre in Russian and world literature since the beginning of the 19th century. In our case, we deal with a piece of literary work with some elements of folk fairy tales produced by a self-made amateur writer.

2 Maria Pakhomovna has a solid Russian Old Believer background. She was born into an Old Believer family and married a man who shared the same religious beliefs. The Rezhica (Rezekne) district has been and remains in to day one of the largest Russian Old Believer settlements in Latvia.

3 See the Language section of the article

4 Note that all her poetry, including this poem, are written in standard Russian without any trace of the local dialect.

5 The word "спектакль" has a figurative meaning of somebody's extravagant behavior, e. g. to show off

6 More details on ethnographic particularities of the story are provided in the section Ethnographic value of the story settings.

7 This appearance also resembles the appearance of a heroic main character in folk or literary tales.

\section{BIBLIOGRAPHY}

Koroleva, Е. А. 2006. Королева, Е. А. Unpublished materials and interviews of M.P. Blokhina.

Zaitsev, Daniel. 2015. Зайцев, Данила. Повесть и житие Даниль

Терентьевича Зайцева [The Tale and the Life of Daniil

Terent'evich Zaitsev]. Ровнова Олга Г. ed. Москва: Альпина

FOLKLORICA 2016, Vol. XX 
нон-фикшн.

\section{APPENDIX \\ FULL TEXT OF STORY}

“Принуждённая любовь”

Охотники собрались на охоту, отвязали своих собак и ушли. После полудня явились к нашему хозяину и на лошади отвезли убитую косулю. Все гурьбой весело со смехом потащили косулю в сарай, там её разделали и ушли все по домам. Хозяйка взялась стряпать привлекла меня с Павлиной. Мы ей помогали, мололи мясо, делали котлеты, пекли печенье и помогли накрыть в зале стол. Когда было всё готово, хозяйка начала звонить по телефону и приглашать всех, кто участвовал на охоте. Явились все со своими жёнами, но из них один был холостяк, парень лет 27-28, белокурый, стройный, с голубыми глазами и с бледным румянцем на щеках. Я с Павлиной находилась в кухне, так как хозяйка просила нам помочь ей в приготовлении добавочной пищи. Мы резали хлеб, хозяйка то и дело выходила на кухню и приказывала нам наложить в тарелки тушёную с мясом картофель, то котлеты или добавить печенье. Белокурый блондин часто выходил на кухню и заводил с нами разговор. Обращался он больше к Паулине, смеялся, шутил, в отдельных случаях критиковал только себя. Паулина разговаривать и шутить с ним не хотела, отвечала ему грубо, отрывисто, но он делал вид, что как будто эта грубость к нему не относится. Он всё больше впивался в её глаза и пристально рассматривал её. Паулина очень красивая девушка: глаза чёрные, искристые, волоса тёмные, вьющие, длинные, лицо смуглое с румянцем и статная фигура, между прочим, что разрисованная мадонна. Блондин, наконец, спросил, как вас зовут. Первая ответила я, Паулина своего имени не назвала, ответила за её я: «Паулина по-русски, а по-латышски будет Паула, - так и будем звать Паула, - а меня зовут Валдис». Тут из зала открылась дверь и Валдиса позвали, он ушёл. Я стала спрашивать у Паулы, почему ты так грубишь? - А потому что FOLKLORICA 2016, Vol. XX 


\section{A Love Story by a Distinguished Russian Old-Believer 69 Storyteller from Latgalia}

я его хорошо знаю. Когда я была маленькая, пасла у Рексте Александры коров, он был такой длинный верзила и пас своих коров, а земли их граничили, и вдруг моя корова перешла через границу на их землю, я как-то не углядела. Он кнутом отстебал корову и меня и заявил: «Ну, несчастный цыганёнок, ещё раз пустишь коров в наш хутор, я тебя выстебаю крепче». Я в ту же очень пошла в школу в первый класс, а он ходил уже в шестой. Я стояла в коридоре, он бежал и дёрнул меня за косу и сказал: «И ты тут, цыганёнок»?

И снова Валдис появился в кухне, но уже был под хмельком, рассказывал смешные анекдоты, был очень весел, брал из тарелок печенье, которое мы приготовили по приказу хозяйке для гостей, преподносил нам: «Угощайтесь, девочки, не стесняйтесь»! - и снова его позвали в зал, он ушел. Через несколько минут явился снова, в руках держал стакан с самогоном и на вилке котлета и стал предлагать Паулине выпить, она категорически отказалась, он её упрашивал, ну выпей немножечко! Та категорически отказалась. «Ну выпей хотя каплю, - нет! - но хотя помочи губы». Паула взяла стакан и прильнула губами: «Ну вот, спасибо, а теперь закусите». Паула немного откусила котлеты и сказала спасибо. Затем он сказал, будьте здоровы и выпил самогон, запихнул в рот котлету, улыбнулся - теперь всё в порядке. И снова его позвали.

Хозяйка вышла, забрала тарелки с картофелем и капустой и сказала : «Теперь можете идти спать». Сначала гости громко говорили и смеялись, потом начали петь. Мы уснули.

Валдис - единственный сын у родителей, он учился в Риге в Медицинском институте. Когда началась война и немцы оккупировали Латвию, началась мобилизация, и чтоб его не взяли на фронт, мать его привезла домой и устроила работать айсаргом, так как айсаргов не брали на фронт, они воевали в тылу, но поскольку он ученый, не воевал, а находился в конторе писарем. Отец старый, седой, лет семидесяти с лишком, мать молодая пятидесяти лет, красивая, голубоглазая, румяная женщина. Сын очень похож на неё. Сама она из работниц, замуж вышла за старика из-за хозяйства, хотя в то время он был не так уж стар: сорок лет, ей двадцать, в то время разница была 
небольшая, а вот теперь заметна: он сед и неуклюж, вечно ходит с верёвками и хомутами, выводит и заводит лошадей. Мать, наоборот, опрятная, чистая, разговорчивая, приветливая к людям. Богатые они не были и держали только одну работницу, и сами работали всю работу.

Наутро мы проснулись как обычно в четыре часа, первым долгом доили коров, приготовили молоко для отправки на сепараторный пункт, перемыли посуду и стали кормить свиней, в это время всегда хозяйка варит завтрак, завершили полностью утреннюю работу и пошли завтракать. Пазавтракав, мы с Паулиной начали убирать посуду. На велосипеде приехал Валдис, вошёл в кухню, поздоровался, спросил, хозяин дома. «Да», - ответила хозяйка и показала рукой на дверь в зал. Валдис вошёл и быстро вышел, утирая платком губы. «Девочки, что вам помочь»? - произнес он весело, Паулина резко ответила: «Ничего»! Но он как бы и не услыхал. Елизавета Яновна, дайте мне фартук и платок! Хозяйка, смеясь, пошла в комнату, принесла ему фартук и платок, он тут же принарядился и весело перекрутился на одной ноге: «Правда, девочки, красиво»? Мы с Паулиной переглянулись и улыбнулись, но ничего не сказали. Он был в платке и фартуке похож на девушку. После похмелья румянец разыгрался на щеках, голубые глаза стали ещё голубей, а вот фигура не подходила к женской, слишком широкоплеч. Он пошёл в зал, собрал со стола посуду и стал носить в кухню. «Куда, девочки, эту ценность»? Паулина показала пальцем на котёл с горячей водой. Он осторожно опустил в воду стопу грязной посуды и, в шутку выставляя себя за женщину, подался за другой партией. Переносив всю посуду, взял полотенце и начал утирать посуду. И так мы мыли посуду. Паулина мыла, Валдис утирал, я разбирала по категориям и носила в буфет. Затем я мыла в зале пол, а Паулина ушла ломать листья свеклы для свиней, с ней пошел и Валдис. Паулина наломала столько листьев и взвалила ему на плечи, что он чуть приволок эту ношу. Сбросил в сарае на пол и тут же уселся на листья и стал отдуваться. Паулина стояла напротив и громко смеялась. Пока они секли листы, я закончила мытьё. Настало время в обед кормить свиней, на 


\section{A Love Story by a Distinguished Russian Old-Believer 71 Storyteller from Latgalia}

помощь позвали меня. Павлина заправляла вёдра кормом, Валдис носил вёдра в свинарник, а я разливала по корытам. Паулина стала почему-то веселее, смеялась и подмигивала мне. Но её ехидство я понять не могла. Может, потому что была совсем мала - 15 лет. Итак, Валдис стал появляться к нам часто. Ему очень нравилась Паула, как он ее называл. Но она к нему была очень колка, выходила из себя, бросала обидные слова. Ты хозяйский сынок, неженка, а я работница. Ты айсарг, я вас ненавижу. При этом он молчал только заливался краской. Обиженный, садился на велосипед и уезжал домой, но наверно, обида отходила быстро, и он появлялся снова.

Уже начался сентябрь, обмолотили хлеб. В обед коров доить перестали, с утра до вечера они находились в загонах. Поравняли в хлеве навоз и пошли в сарай за соломой для постилки. Первое беремя навязали мне, Валдис приподнял его мне и я понесла в хлев, второе беремя остались вязать Валдис и Павлина. Я своё беремя уже растрясла и пошла опять в сарай, а у них в сарае концерт: Валдис сидит на береме и платком вытирает кровавые полосы. Паулина стоит в углу и перечитывает, какой он есть. Он встал, глаза у него были грустные. Он обратился ко мне: «Марья, подыми»! Я подняла ему на плечи беремя, которое было навязан чуть ли не с лошадиный воз, снёс солому в хлев, сбросил, взял велосипед и уехал, ничего не сказав. Я Паулине задала вопрос, почему вы подрались? - «Как же, стянули беремя, связали, и он меня схватил за руки, прижал к беремю и хотел поцеловать, вот я его и разукрасила, - и засмеялась, - теперь такой красивый больше не появится. Но мне его не жаль. Ведь он так ей всегда старался делать доброе, а она как кошка все время его порет, если не словами, то когтями.

Вот уже и конец сентября. Молотилка приезжает от соседа к соседу, мы с Паулой ходим отрабатывать за нашу молотьбу. Домой приходим поздно вечером усталые и снова подымаемся в четыре утра. Хорошо, что вечером хозяйка управляется с хозяйством сама. Пришла очередь молотить у Бривкална. Пошли работать мы втроем: хозяин, я и Паула. Бривкалнс хозяин зажиточный, хлеба много, рабочих собрал на две смены, 
работали по два часа и снова менялись. На обед столы накрывали в большом зале и в первую очередь посадили обедать хозяинов и их сынов и дочек, а работников и работниц во вторую застолицу. Рабочие начали роптать, мол, мы, свиньи, должны обедать после господ. Валдис подошел к Паулине и стал звать ее за стол, она категорически отказалась, заявив, что она работница и обедать пойдёт только с работниками. Валдис тоже не сел за стол, а вместе с нами ждал вторую застолицу. Отобедав, снова взялись за работу. Я и Паула отпихивала солому от машины. Её брат Саша лошадью, запряженной в жердь, оттягивал солому к стогу. На стог подавали Валдис и незнакомый мужчина. Метали стог Шура с мужем, работ много, всех не перечислить. Наш хозяин оттягивал и подвешивал мешки под зерно. Сам Бривкалнс зерно возил в амбар.

Начало темнеть. Старый Бривкалнс принес фонари и навешал где можно. Молотили при тусклом свете, и работа уже шла к концу. В последнюю очередь начали молотить горох. Как раз меня, Паулину и Сашу заменила наша смена. Паулина послала меня за горохом, и я пошла, в мешках уже был горох. Я протянула Сашину шапку к хозяину и попросила, чтоб он мне насыпал гороху. Он взглянул на меня и улыбнулся, я была похожа на бесёнка, чумазая, вся в пыли, глаза слипались, хотелось спать. Он спросил, устала, да? Тогда он отодвинул мешки, бросил между мешков охапку соломы и сказал, ляг отдохни и больше не ходи туда, без тебя домолотят, и забросал меня пустыми мешками.

Валдис к нам не подходил, хотя и работал рядом, даже в пересменку ни разу не подошёл, садился под стог и сидел со своим напарником. Паула всё время смотрела, как он работает и ехидно высмеивала: «Сегодня нежные ручки получат кровавые музули», - хотя у неё уже были на своих руках музули. Паулина с Сашей не дождались меня. Саша пошел меня разыскивать, подошел к мешкам, где работал наш хозяин, спросил, где Мария, хозяин ответил, не видел, а сам случайно взглянул в то место, ге я лежала. Саша, уловил взгляд и полез через мешки в мое гнездо, и стал откидывать пустые мешки. Я 
уже спала, спросонья испугалась и уцепилась ему в волоса, я в впотьмах его не узнала, думала, что кто-то чужой, и так его дёрнула, что он закричал. Хозяин хохотал от души и подтрунил, так что Саша ушёл, и я снова уснула. Проснулась тогда, когда брали последние мешки. Рабочие всё подграбили, подчистили. Которые освободились от других работ, обчасывали стог граблями, а солому подпихивали к Валдису, остатки соломы он кидал на стог, один напарник стоял и курил. Пришёл старик Бривкалнс снял фонари, погасил, один фонарь повесил на улице около дома. Хозяйки вынесли на двор теплую воду в ведрах и тазах, а также мыло и полотенце. Все вымылись, у кого была запасная одежда, переоделись. Валдис уехал домой, мы с Паулой зашли в работницкую комнату, там лежала наша запасная одежда, переоделись, расчесали свои волоса, поскольку они у нас были длинные, но за день тяжелой работы они растрепались и сбились, заплели косы, уложили аккуратно, переоделись. Когда все были уже в порядке и все собрались, хозяйки пригласили на ужин. Явился и Валдис в голубой рубашке, галифе и начищенных до блеска хромовых сапогах. Царапины на лице еле заметны. Взглянув на него, Паула улыбнулась и молвила, а следки ещё заметны.

На этот раз ужинать в первую очередь пригласили работников, и снова начался ропот, что в первой застолице надо торопиться, чтоб дать место другой, а другая может не торопиться, сидеть, сколько им захочется, торопить никто не станет, работа кончен. Работали больше мужчиы, им жаль было упустить лишнюю кружку пива. Хозяйки волновались, но молчали. К нам снова подошёл Валдис и предложил Пауле ужинать во второй застолице, Павлина с каким-то юмором отказалась, и мы пошли за стол. Валдис тоже сел с нами, но на этот раз сел около меня. Молчал, не заводил никаких разговоров, наверно, затаил в душе обиду. Молчала и паулина. Поужинав, мы пошли в работницкую комнату. Валдис с мужчинами пошёл на улицу курить. После ужина разобрали столы и объявили танцы. Играть были приглашены два аккордеониста, молодые, красивые парни, они играли посменно.

FOLKLORICA 2016, Vol. XX 
Женщины и девушки сидели вдоль стен на скамейках, мужчины стояли, столпившись у дверей. Аккордеонист заиграл первый вальс. Пырвыми вышли Шура и Паулина, они кружились плавно, красиво, несколько минут никто не выходил на круг. Все смотрели, как кружатся девчата, русские и кружатся по-русски, у них получалось здорово. Затем стали выходить пара за парой, и заполнился весь зал. Валдис стоял около порога рядом с нашим хозяином, о чем-то говорил с ним и искоса посматривал на Паулину. Паулина уловила взгляд Валдиса и шепнула Шуре, когда Валдис нацелится на меня приглашать, тут же ты сразу приглашай меня, чтоб он не успел ко мне подойти. Танец кончился, женщины расселись по местам. Тут и началась для Валдиса нервотрёпка. Это Паулине и Шуре удалось сделать несколько раз. Шура её не приглашала тогда, когда ее приглашал какой-нибудь парень или мужчина. Паулина прельщала всех своей красотой и стройной фигурой. Сколько было на неё взоров! Со стороны всё видно, поскольку я в свои 15 лет была пигалицей и не танцевала, потому что не умела. Понравилась Паулина и аккордеонистам. Когда один играл, другой всё время приглашал её на танец, потом заменял другой. А Валдису так и не подходила очередь. Вдруг объявили отбивной танец: парни хлопали в ладошки и отбивали девушек от парня, с которым она танцует, а тот отбивает другую девушку. Тут вышла очередь Валдису.

Павлина как раз танцевала с аккордеонистом. Валдис подошёл, улыбнулся и легонько хлопнул в ладошки. Паулина сделала вид, что она не заметила, уцепилась крепче в партнёра, крутанулась и хотела скрыться среди танцующих, но не тут-то было! Валдис схватил ее за руку и ударил по щеке, выдернул её из круга и посадил рядом со мной и сел рядом с ней сам. Её партнер юркнул в танцующий круг и скрылся, как видно, испугался тоже. Все бросили взор на них, даже в зале воцарилась тишина. Паулина сидела, не шевелясь, глаза ее стали больше и чернее, они не моргали, но слёзы катились крупные как горох. Валдис молчал, но был бледный, как лист бумаги. И тут она взглянул в лицо Павлине и сразу вздрогнул, увидев её слёзы, вынул из кармана платок и утёр ей слёзы. 
A Love Story by a Distinguished Russian Old-Believer 75 Storyteller from Latgalia

Павлина не шевельнулась от страха. Тогда он прижал её голову к груди, зажмурил глаза и губами прижался к ее волосам. На этот спектакль обратили все внимание. Наш хозяин заметил это тоже, и его задело, что при людях так обидел его работницу. Хозяин пальцем поманил Валдиса, Валдис встал, пожал руку Павлине, извинился и подошел к хозяину, хозяин его хлопнул по плечу и стал потихоньку выпихивать из зала. Они вышли. Павлина шепнула мне, что она должна бежать домой, но как сделать, чтоб никто не заметил? Мы взялись за руки и пошли из зала. Выйдя из зала мы заметили хозяина и Валдиса, они стояли у самых дверей и курили, хозяин что-то строго говорил Валдису.

Мы шмыгнули в работницкую комнату, работник и пастух уже спали. Я разбудила пастуха, так как он был мой братенник, он поднялся, открыл окно, Павлина одела пальто. И мы вылезли на улицу. Я ее довела до большой дороги, и она побежала, а вернулась, влезла через окно и села на своё место. Вскоре вошли в зал хозяин и Валдис. Заметив, что рядом со мной нет Паулины, Валдис подошёл ко мне, сел и спросил, где Паула. Не знаю. Он меня крепко сжал за руку выше локтя: «Говори, где Паула»? - а сам глазами шьёт по залу. Мне стало больно руке, и я сказала, что она пошла домой. На первый раз он не поверил, потому что стоял у самых дверей и пройти незаметно она никак не могла, сжал руку мне сильнй: «Говори, где она»? Мне стало больно руки и страшно тоже, ведь он айсарг. Я подумала, что она уже далеко, не догонит, и сказала, что она ушла через окно. Он бросил мою руку и быстро рванулся на двор. Хозяин наблюдал за ним, тоже бросился сзади. Валдис схватил велосипед и помчался вдогонку за Паулой. Паула бежала со всех сил, потому что было очень темно и до дома три километра. И вдруг ей осветилась дорога, она бежала и кого-то благодарила за освещение дороги, не подозревая, что это Валдис, у которого на велосипеде динамик. Хозяин на своем велосипеде гнался за Валдисом, я осталась одна, овладел мною ночной страх и решила бежать за хозяином, но соревноваться с ними мне не удалось, я далеко отстала от ночного финиша. Дорога очень ровная, даже срезан горки, по обочинам только 
кусты и местами горные срезы. Паула бежала, а свет всё ближе и ближе, и вдруг пистолетный выстрел. Она пригнула голову, бросилась в сторону, не рассчитав в темноте, сильно ударилась головой в срез, отвалилась назад и потеряла сознание. Валдис бросил велосипед на дороге и бросился к ней. Она лежала вверх лицом, лицо было в песке, даже во рту был песок. Валдис положил ее голову себе на колено и стал утирать лицо платком. И тут подъехал хозяин, он слышал выстрел, набросился ругать Валдиса, что он застрелил девушку. Валдис отпирался, доказывал, что он выстрелил вверх. Тут подбежала я и вижу спектакль не очень приятный, начала плакать, хозяин на меня: «А ну брысь домой»! Я со слезами побежала домой. Двери открыла мне хозяйка, вот тут я ей оповестила, что Валдис застрелил Паулину. Хозяйка забегала по кухне, закрутила себе руки, начала кричать, ругать Валдиса и вместе хозяина, что он не сохранил Паулину. Пока мы плакали, смотрим, хозяин открывает дверь, Валдис на руках вносит Паулину. Хозяйка пустила в ход своё горло и получила что и я: «А ну брысь»! Хозяйка притихла. Павлину Валдис положил на ее кровать и объяснил хозяйке, как всё произошло, что ей ничего страшного нет, небольшое сотрясение и попросил полотенце. Хозяйка вынесла полотенце, он сам смочил его водой, пошёл в комнату и начал обтирать ей лицо, обтёр лицо. Она лежала как мёртвая, даже не шевельнулась, а когда он хотел ей на груди расстегнуть пуговицы, она уцепилась ему за руку. Хозяин, наблюдая за ними, улыбнулся и ушел в кухню. Хозяйка была в ярости, ей так и хотелось броситься на хозяина, но он снова на ней брыснул, и она ушла в свою комнату. Я осталась на кухне, боялась войти в комнату, чтоб не помешать Валдису ввести Паулину в сознание. Потом вышла хозяйка и позвала меня к себе, постелила мне на лежанке, я сразу уснула.

Наутро мы с хозяйкой всё делали сами: доили коров, кормил и завтрак варили, Паулина отдыхала. Выдоивши коров, я одним глазом заглянула в комнату, Павлина не спала и подмигнула мне глазом. Валдис сидел на её кровати, облоктивши через её, всё клевал носом ей в грудь. Пока мы прибирались, я не видела, как он уехал домой. К обеду Паулина 
встала, помогала мне кормить свиней. Я спросила: «Ну, как здоровье»? Она ответила: «Немного болит голова». И зашел у нас разговор о долге, я сказала ей пословицу: долг платежом красен. Ты его разукрасила, а он тебя, теперь вы в расчете. Она засмеялась и сказал, ему это так не пройдёт. Я ему ещё чтонибудь подстрою. Пообедав, мы пошли в свою комнату отдыхать, и все смеялись случившемуся вчера, расплели свои волоса, чтоб почесать и привести в порядок головы. И вдруг послышались по кухне шаги. Я думала, что идёт работник, представила себя ведьмой с распущенными волосами и нацелилась спугнуть его, а в дверях оказался Валдис. Я отскочила и бросилась на кровать, Паулина расхохоталась, Валдис не понял, о чем мы так смеёмся, и начал спрашивать то в одной, то в другой и что смешное скушали, осмотрел себя, ему казалось, что смеёмся около него, и покраснел. Вскоре пришёл работник, поздоровался с ним, и чтоб не мешать нашей компании, ушел в сарай колоть дрова. Я прибрала волоса и тоже пошла на улицу.

Наступил октябрь. Воскресенье, день красивый, солнечный. Мы прибрались в обед и решили идти гулять, прибрали себя в порядок и только вышли на крыльцо, тут же на своей рысачке приехал Валдис с матерью, соскочил с линейки и подошёл к крыльцу и спросил, куда, девочки, направились? Паулина ответила: «Гулять! - Возьмите меня с собой». Пока торговались о прогулке, вышла на крыльцо хозяйка и стала приглашать его и мать в дом. Мать привязала лошадь, подошла к Валдису, дёрнула его за рукав, что значило - пошли в дом! Затем вошли все трое в дом. Мы не успели отойти от крыльца, нас окликнула хозяйка позвала в дом. Мы вернулись, зашли на кухню. Хозяйка стала звать Паулину в зал. Паулина отказалась, хозяйка сказала: «Мария, пошли тоже»! Я собралась идти и потащила за собой Паулину. По-видимому, хозяйка их ждала, потому что в зале был накрыт стол и стояла бутыль с самогоном. Хозяйка пригласила сесть всех за стол. Мать Валдиса Эльза Яновна оказалась женщина очень приветливая то ли хитрая: она так и разливалась, расхваливала нас, а сына критиковала, но было видно, что она от сына без ума. Казалось, 
что бы сын у неё ни потребовал, она бы всё выполнила. Хозяйка разлила самогон по маленьким стаканчикам и предложила всем выпить. Мы все опустошили свои стаканчики. Две хозяйки, две подруги, болтали о разном, а мы чувствовали себя не в своём кресле. Как-то было неудобно, говорить было не о чём, Валдис поглядывал на Паулину. Через минуты три я почувствовала что-то невероятное в голове, посмотрела в окно, на улице всё двигалось, и почему-то мне стало смешно. Хозяйка заметила, что я опьянела и убрала мой стакан. Когда она начала разливать второй раз, я взглянула на свой стакан, а его уже не было, все засмеялись, а я не растерялась, взяла вилку и нож и выбрала самый большой кусок курицы и начала кушать, а Паулина получила вторую порцию самогона. Когда у Паулины заиграл румянец на щеках, её стакан тоже исчез. Остальной самогон допивала хозяйка с гостями. Когда трапеза шла к концу, Эльза Яновна предложила проехать на рысачке: «Ну, молодёжь, хватит сидеть, покатайтесь, а то лошадь состоялась». Мы стали выходить из-за стола. Валдис взял Паулину за руку и предложил кататься. Паулина отказалась, но он так привязался и не выпускал её руку. Она что-то чувствовала и сказала, если поедет Марья, тогда поеду и я, но я быстро отказалась. На улицу выщли Эльза Яновна и хозяйка и стали уговаривать Паулину, чтоб она ехала с Валдисом кататься. Эльза Яновна скзала: «Я вас подожду здесь, мы ещё поговорим с Елизаветой Яновной». Паулина села в линейку, мать отвязала лошадь, подала вожжи Валдису. Лошадь рванула, свернув на большую дорогу, помчалась в сторону Бривкалнов. Эльза долго не задержалась у нас, она пошла на перекрёсток, где Валдис должен был свернуть в сторону своего дома. Я смотрела в окно и ждала, когда они вернутся, но они так больше и не вернулись к нам. Мать их встретила на перекрёстке, села к ним в линейку и взяла вожжи в руки, Паула нацелилась сойти с линейки, но Валдис её не пустил, охватил обоими руками и крепко прижал к себе. Мать дёрнула вожжи, повернула лошадь на свою дорогу, и они помчались домой. Я тогда поняла, что это был сговор. Лошадь у дома встретил отец, взял её под уздцы. Валдис соскочил, взял за руку Паулину и стал помогать ей сойти с 
A Love Story by a Distinguished Russian Old-Believer 79 Storyteller from Latgalia

линейки, мать, ловко спрыгнув на землю, подхватила Паулину под руку: «Зайдём к нам в гости, ты ведь ни разу не была у нас». Паулина смотрела на них испуганными большими чёрными глазами и не знала, что сказать. Мать лепетала, как птичка, своим нежным голоском, но Паулина её не слыхала. От волнения у нее прилила кровь к голове, она хотела освободиться от них, но сильные мужские руки крепко ее держали, и она невольно пошла в дом. На кухне чем-то занималась работница, паулине было не до неё. Мать начала её знакомить с домом. Пройдя кухню, вошли в комнату, мать объяснила, что это комната их с отцом, а следующая Валдиса, и пошли в другую комнату. Валдис всё время держал её за руку, пока не вошли в его комнату. В комнате стояла кровать, небольшой столик возле окна и одна табуретка. Мать быстро развернулась и ушла, принесла вторую табуретку, предложила сесть Паулине, пошла заварить чай. Паулине сжалось сердце, она почувствовала, что здесь что-то вроде ловушки. Её чувство оправдалось. Валдис пододвинул свою табуретку, сел рядом и стал объясняться в любви, но Паулина подчинялась только своей гордости. Она резко отвергала его предложения и просила отпустить её домой. Вошла мать, принесла чай, но пить чай никто не стал. Валдис был очень расстроен, глаза его были наполнен слезами. Мать, заметив его переживания, вступила в сватовство. Она даже умоляла Паулину остаться, говорила, что она слышит через стенку, что сын не спит, ворочается, вздыхает: «Валдис очень любит тебя, тебе не будет у нас плохо, мой сын очень хороший и умный, ему помешала война закончить Медицинский институт, когда кончится война, он его закончит, и вы будете счастливы».

.Осенний день короткий, наступали уже сумерки. Паулина сидела, облокотивши на стол и, опустив голову, больше ничего не отвечала Валдису. Валдиса жгла обида, временам он становился злой и начинал грубить, но ей ничего не помогало, она стояла на своём, изредка заявляла выпустить её, Валдис отказывал категорически. Открылась дверь, мать с работницей тащили кровать, которая была лишней в работницкой комнате. Кровать поставили на противоположной стороне, принесли 
матрас, набитый свежей соломой, в комнате запахло свежим воздухом, смешанным с соломой. Мать принесла подушку, постелила льняную простынь и застелила кровать самотканым шерстяным одеялом с латышским орнаментом. Улыбнулась, сказав: «Это тебе, невестушка», - и ушла. Совсем стемнело, зажгли керосиновые лампы, но Валдис в своей комнате лампу не зажёг, лег на кровать во всей одежде, заложил руки за голову и смотрел в долгий потолок. Паулина в эту минуту думала, что сейчас думает о ней хозяйка, не подозревая, что её хозяйка продала в жены Валдису. В доме было тихо, отрывкам что-то бубнил отец, из-за стены ничего не разобрать. Затем тишину нарушил Валдис, он поднялся, сел на кровать и сказал: «Паула, ложись спать, не бойся, я не зверь, не съем тебя, мне тоже надо спать, завтра рано на работу. Так и раздеваясь, повернулся к стене.

Паулинаа не легла, она сидела и думала над всем, что произошло сегодня, вспоминала прошлое, вспомнила, как она ему оцарапала лицо, зачем ей это надо было делать? В тайне своей души она стала обвинять себя, а зачем сделала ему на танцах перед всеми такую неловкость, значит, получила пощёчину по заслуге. Вспомнила, как он нёс домой, прижав её к своей груди, его тяжелое дыхание, как ему было тяжело её нести. Ей стало его жаль, в душе его она уже давно любила, но любви не корилась, а корилась своей гордости. Утром Валдис проснулся рано, зажёг лампу, сел к столу, взял её руку и поцеловал: «Почему ты мне не веришь, всё будет по закону, обвенчаемся, сделаем свадьбу». Паулина заплакала и сказала: «Мою мать тоже сватали, она была красивой, и что получилось? Нас у неё трое, и все от разных мужчин. Вы, хозяйские сыны, хотите всё с нами играть и за это мы должны нести позорный крест». Валдис посмотрел на часы и сказал, мне пора на работу, подошёл к Паулине, поцеловал в лоб и сказал, я вернусь скоро. Лошадь была уже запряжена. Он быстро вышел, что-то сказал матери и уехал.

Паулина прилегла на кровать и скоро уснула. Спала весь день, проснулась, когда услыхала быстрые шаги, вскочила и села на кровать. В комнату вошёл Валдис, глаза у него были 
A Love Story by a Distinguished Russian Old-Believer 81 Storyteller from Latgalia

злые, лицо бледное, весь раздраженный, быстрым шагом подошёл к Паулине. «Паула, - спрашиваю в последний раз, согласна стать моей женой, да или нет»? Паулина не сказала ни да, ни нет, а сказала: «Отпусти меня домой! - Сейчас ты будешь свободна»! - и вынул пистолет из кобуры. Паулина онемела, не могла ничего сказать, только закричала. Когда он наставил пистолет себе к виску, она бросилась к нему на шею и громко крикнула: «Не надо»! Валдис отпустил руку вниз, левой рукой прижал Паулину к себе, затем выстрелил в потолок. Мать, услышав выстрел, пала в обморок, было слышно, как она громнулась о пол. Валдис бросился к матери. Она лежала на полу, он зачерпнул стакан воды стал тихонечко трясти мать: «Мама-мама, очнись, ничего не произошло»! Мать открыла глаза, он преподнёс ей стакан с водой, она глотнула глоток и сказала: «Ты жив, а девушку убил»? - и снова пала в обморок. Валдис позвал Паулину, Паулина подошла, Валдис попросил помочь положить мать на кровать. Мать пришла в себя, увидела, что сын с девушкой стоят рядом, улыбнулась и спросила: «Кого же ты застрелил»? Валдис в шутку ответил: «Муху на потолке».

Свадьба была скромной. До родов оставалось совсем немного времени, Валдис уговаривал жену не бояться при родах. Он говорил, я сам буду присутствовать при родах и говорил в шутку, ведь я без одной недели хирург.

FOLKLORICA 2016, Vol. XX 